УДК 330.1

\title{
ПОРІВНЯЛЬНИЙ АНАЛІЗ ТИПІВ РИНКОВИХ СТРУКТУР
}

\section{COMPARATIVE ANALYSIS OF TYPES OF MARKET STRUCTURES}

\author{
Микуланинець Світлана Іванівна \\ кандидат економічних наук, \\ Мукачівський державний університет \\ ORCID: https://orcid.org/0000-0003-3756-0901
}

\author{
Mykulanynets Svitlana \\ Mukachevo State University
}

\begin{abstract}
У статті проведено порівняльний аналіз основних типів ринкових структур. Розглянуто характерні ознаки, на основі яких визначається модель ринкової структури. Охарактеризовано рівень конкуренції, як ключовий фактор визначення моделі ринку. Проаналізовано особливості, переваги та недоліки кожного типу ринкової стуктури. Обгрунтовано економічну ефективність ринку досконалої конкуренції. Визначено ключову перевагу ринку монополістичної конкуренції, яка полягає в диференціації товарів та послуг, а також методів їх просування. Здійснено аналіз основних можливостей та загроз олігополістичного ринку. Охарактеризовано загрози та негативні наслідки монополій, а також необхідність державного контролю за цих умов. Відображено особливості реальних та «ідеальних» ринкових структур. Визначено економічно найефективніші моделі ринку.

Ключові слова: конкуренція, тип ринкової структури, досконала конкуренція, монополістична конкуренція, олігополія, монополія.
\end{abstract}

В статье проведен сравнительный анализ основных типов рыночных структур. Рассмотрены характерные признаки, на основе которых определяется модель рыночной структуры. Охарактеризованы уровень конкуренции, как ключевой фактор определения модели рынка. Проанализированы особенности, преимущества и недостатки каждого типа рыночной стуктури. Обоснованно экономическую эффективность рынка совершенной конкуренции. Определены ключевое преимущество рынка монополистической конкуренции, которая заключается в дифореренциации товаров и услуг, а также методов их продвижения. Осуществлен анализ основных возможностей и угроз олигополистического рынка. Охарактеризованы угрозы и негативные последствия монополий, а также необходимость государственного контроля в этих условиях. Отражены особенности реальных и «идеальных» рыночных структур. Определены экономически эфрфективные модели рынка.

Ключевые слова: конкуренция, тип рыночной структуры, совершенная конкуренция, монополистическая конкуренция, олигополия, монополия.

The article presents a comparative analysis of the main types of market structures. The characteristic features on the basis of which the model of market structure is determined are considered. The level of competition is characterized as a key factor in determining the market model. Features, advantages and disadvantages of each type of market structure are analyzed. The economic efficiency of the market of perfect competition is substantiated. The key advantage of the market of monopolistic competition, which consists in the differentiation of goods and services, as well as methods of their promotion, is determined. The analysis of the main opportunities and threats of the oligopolistic market is carried out. The threats and negative consequences of monopolies, as well as the need for state control under these conditions are described. Features of real and "ideal" market structures are reflected. The most economically efficient market models have been identified. A market economy is a complex and dynamic system of economic relations between sellers, buyers and other entities. This causes the heterogeneity of markets, namely their difference in certain parameters: the number and size of enterprises operating in the market, their ability to influence the price level, the type of goods offered and much more. Based on these characteristics, the type of market structure or otherwise the market model is determined. However, in today's market conditions it is quite difficult to clearly define to which type of market structure to attribute a particular market for goods and services. The purpose of the study is to conduct a comparative analysis of the main types of market structures, in order to determine their advantages and disadvantages. The market of absolute competition is characterized by a high level of economic efficiency. With regard to monopolistic competition, this is the type of market structure that needs to be regulated. 
A significant advantage of this structure is the variety of goods. Oligopolies are effective in developing and implementing certain innovations. In general, the spread of monopoly negatively affects the level of economic efficiency of the market, as the monopolist aims to maximize profits with minimal production, as a result, available resources are not fully used and consumers do not receive the required number of products, low production efficiency.

Keywords: competition, type of market structure, perfect competition, monopolistic competition, oligopoly, monopoly.

Постановка проблеми. Ринкова економіка $є$ складною та динамічною системою господарських взаємовідносин між продавцями, покупцями та іншими суб'єктами. Це зумовлює неоднорідність ринків, а саме їх відмінність за певними параметрами: кількість і розмір підприємств діючих на ринку, їх здатність впливати на рівень цін, вид пропонованих товарів і багато іншого. На основі цих характеристик визначається тип ринкової структури або інакше ринкова модель. На сьогоднішній день виділяють чотири основні типи ринкових структур: чиста (досконала) конкуренція, монополістична конкуренція, олігополія і чиста (абсолютна) монополія. Проте в сучасних ринкових умовах досить складно чітко визначити до якого типу ринкової структури віднести той, чи інший ринок товарів та послуг.

Аналіз останніх досліджень і публікацій. Вагомий внесок в дослідженях цих теорій належить А. Сміту, Д. Рікардо, А. Маршалл, Э. Чемберлин, Дж. Кейнс, Й. Шумпетер, М. Портер, А. Юданов, Р. Фатхутдінов, С. Толкачов та інші. В своїх працях науковці здійснили аналіз проблем конкуренції та дослідження різнорідних ринків. Проте залишаються актуальними питання фрормування ефективної поведінки суб'єкта господарювання в тих, чи інших ринкових умовах.

Мета дослідження: проведення порівняльного аналізу основних типів ринкових структур, 3 метою визначення їх переваг та недоліків.

Виклад основного матеріалу дослідження. Ринкова структура залежить від кількості та розмірів підприємств, характеру продукції, доступності інорормації та наявності бар'єрів входу на ринок та виходу з нього. Типи ринкових структур відрізняються за рівнем конкуренції, за характером взаємодії суб'єктів господарських відносин, за шляхом формування цін та ін. Типи ринкових структур визначаються на основі таких ключових характеристик:

- кількість підприємств, які здійснюють свою господарську діяльність на даному ринку;

- розміри підприємств;

- кількість покупців (споживачів) на ринку;

- характеристики товару (послуги);

- бар'єри входу на ринок та виходу з нього;

- доступність інсоормації стосовно рівня цін, попиту на ринку та ін.;
- можливість окремого підприємства вплинути на рівень цін на ринку.

Ключовою характеристикою, яка визначає тип ринкової структури виступає рівень конкуренції, тобто здатність окремого суб'єкта господарювання впливати на загальну кон'юнктуру ринку. Чим вищий рівень впливу окремого суб'єкта, тим нижчий рівень конкуренції на даному ринку. Зокрема конкуренція може бути ціновою, що передбачає підвищення або зниження цін, а також неціновою, яка влючає систему заходів щодо покращення якості товару, вдосконалення дизайну, використання додаткового сервісу, запровадження рекламних заходів тощо.

В науковій літературі виділяють чотири основні типи ринкових структур, а саме: досконала або чиста конкуренція, монополістична конкуренція, олігополія, чиста або абсолютна монополія.

Досконала конкуренція - це ситуація на ринку коли фрункціонує багато підприємств (продавців), що реалізують однорідний товар (послугу) і жодне з підприємств не має вирішального впливу на рівень ринкової ціни. В практиці господарської діяльності досить рідко зустрічаються умови чистої конкуренції на ринку. Проте можна вважати що ринок сільськогосподарської продукції, фрондові біржі, міжнародний валютний ринок відповідають умовам чистої конкуренції, оскільки тут представлені досить однорідні товари та яснує велика кількість продавців.

До основних особливостей чистої конкуренції належать: велика кількість підприємств (продавців), які переважно $€$ невеликими, товар представлений на ринку $є$ однотипним (стандарним), учасники ринку не мають впливу на ринкову ціну, немає бар'єрів входу на ринок, використовується тільки нецінова конкуренція.

Позитивним результатом чистої конкуренції $\epsilon$ ефрективний розподіл обмежених ресурсів 3 метою максимального задоволення споживчих потреб. За умов досконалої конкуренції підприємства здійснюють господарську діяльність до моменту, коли ціна дорівнюватиме витратам, тобто буде вироблено максимально можливий обсяг продукції до моменту отримання нульового економічного прибутку. 
Серед основних негативних наслідків досконалої конкуренції можна виділити такі: відсутність науково-технічного прогресу, окльки підприємства не мають високого рівня прибутковості і достатніх коштів для впровадження та розвитку нових технологій; всі товари $є$ уніфрікованими та стандартизованими, що не відповідає різноманітним, індивідуальним смакам та уподобанням споживачів, які все більше уваги приділяють не лише товару та його призначенню, а й оформленню, упаковці та ін.

Отже, за умов чистої конкуренції усі підприємства реалізовують однотипні товари, при цьому жодне підприємство не володіє перевагами у виробничих обсягах, місці розташування, упакування товарів тощо. Споживачі (покупці) володіють інформацією стосовно рівня цін та надають перевагу товарам ціна яких $є$ нижчою.

Монополістична конкуренція - це тип ринкової структури в умовах якої фрункціонує відносно багато підприємств (від 10 до 100), які реалізовують схожу, але диференційовану продукцію. Тому кожен продавець виходить на ринок з своїм специфрічним товаром, який має певні особливості в порівняні зі схожими товарами. До особливостей товару можна віднести покращення основних характеристик, зміна смакових чи ароматичних домішок, зручне розташування та ін.. Не існує особливих перешкод для входу на ринок, тому можуть з'являтися нові конкуренти. Підприємства не можуть значною мірою вплинути на рівень цін, тому здебільшого застосовується нецінова конкуренція (реклама, бренд, торгова марка).

До основних особливостей монополістичної конкуренції можна віднести наступні: порівняно велика кількість продавців на ринку; підприємства є малими або середніми за розміром; велика кількість покупців; диференційовані товари та послуги; обмеженість впливу на ринкову ціну; вільний доступ до інорормації на ринку; незначні бар'єри входу в галузь; переважно здійснюється нецінова конкуренція та обмежена цінова. Позитивною стороною монополістичної конкуренції виступає стимулювання виробництва дисеренційованих товарів та послуг широкого асортименту.

За умов монополістичної конкуренції переважно здійснюється нецінова конкуренція, яка полягає у впровадженні технічних переваг, підвищенні якості та надійності продукту чи послуги, застосуванні більш есрективних методів збуту та інших прийомів.

Олігополія - це тип ринкової структури, за якого на ринку фрункціонують кілька під- приємств (продавців), які займають значну частку ринку, відповідно, зміни в їх господарській діяльності значною мірою впливають на загальну ситуацію на ринку. В умовах олігополії кожен продавець знає, що, прийняті ним рішення впливають на конкурентів, тому повинен враховувати наслідки та можливі дії конкурентів у тій, чи іншій ситуації.

Серед основних рис олігополії можна виділити наступні: обмежена кількість продавців та значна залежність між ними; діяльність підприємств спрямована на збільшення ринкової частки; здійснюється жорстка цінова конкуренція та нецінова конкуренція; часто зустрічається об'єднання та поглиннання фрірм, як найефективніший спосіб збільшення ринкової частки; існують істотні бар'єри входуна ринок.

В умовах олігополії, стратегічна поведінка підприємств направлена на здійснення певної фрорми кооперації, з метою збільшення частки ринку. Однією з фрорм кооперації є картель, основою якого $є$ домовленість між підприємства стосовно обсягів виробництва, рівня цін на товари та послуги, умов найму працівників, виначення частки ринку та збуту кожного учасника. Крім картелю на олігополістичному ринку може здійснюватися «гра за правилами», тут господарська діяльність здійснюється на основі лідерства в цінах або на основі не офіційно прийнятого єдиного рівня ринкової ціни. Особливістю олігополії $€$ те, що дії підприємств взаємозалежні, при зміні ціни одним продавцем $€$ два варіанти поведінки конкурентів, або вони приймають нову ціну і встановлюють таку ж на свої продукти, або ігнорують зміну ціни і залишають ціни на свої продукти незмінними.

До переваг олігополії належить можливість споживача отримати більш дешеві товари та послуги, за умов цінової конкуренції, або більш якісних, при умові, що фрірми конкурують підвищуючи якість товрів. Ринок розвивається більш динамічно за рахунок застосування і цінової, і нецінової конкуренції. На олігополістичному ринку продавці з метою збільшення частки ринку можуть застосовувати наступні зходи: зниження цін, підвищення якості продукції, збільшення обсягів виробленої продукції, 3 метою підвищення рівня прибутковості на основі масштабу. Все це здійснює позитивний вплив на загальну ситуацію на ринку.

Негативний вплив може виникнути за умов виникнення змови між олігополістами, за якої вони встановлять високу ціну і низький обсяг виробництва, що може призвести до кризи в галузі.

Чиста або абсолютна монополія - ситуція на ринку коли на рику діє один-єдиний прода- 
вець унікального товару, який не має близьких замінників. На даному ринку відсутня конкуренція, монополіст має повну владу на ринку, визначає рівень цін та обсяг пропозиції товару на ринку. Існують майже нездоланні бар'єри входу на ринок.

Харктерні ознаки монополії: один основний продавець на ринку, переважно це великі за розміром підприємства; кількість покупців може бути різною; унікальний товар, який не має замінників; монополіст повністю контролює рівень цін; нездоланні бар'єри входу на ринок та відсутність доступу до інформації.

Розрізняють три види монополій залежно від походження: природні, які виникають за об'єктивних причин (природні умови доступу до унікальнх ресурсів, особливі технологічні умови виробництва, тощо); адміністративні виникають за умов надання державою виключного права певному підприємству на здійснення певної господарської діяльності, сюди також можна віднести підприємствамонополісти, діяльність яких захищена патентами, авторським правом, товарним знаком; штучні монополії можуть виникнути внаслідок змови між підприємцями, які прагнуть захопити владу на ринку. Такий вид монополії $€$ протизаконним та забороненим.

Монополія має більше негативних наслідків ніж позитивних. Серед негативних: монопольне ціноутворення, можливе посилення інсрляції, нераціонльний розподіл ресурсів, можливе гальмування нуково-технічного прогресу, посилення соціальної нерівності та ін. Серед позитивних наслідків можна зазнчити те, що в окремих галузях саме монополія $€$ найесрективнішою фрормою господарювання. 3 метою уникнення негативних наслідків держава повинна здійснювати контроль за рівнем цін, якістю продукції та послуг, а також усунення штучних монополій.

Проаналізуємо особливості кожного типу ринкової структури за окремими фракторами: кількість підприємств (продавців), кількість покупців, розміри підприємств, товар, існування контролю рівня цін, існування бар'єрів входу на ринок та виходу з нього, доступність інформації стосовно ситуації на ринку, наявність цінової та нецінової конкуренції.

На основі таблиці можемо зробити наступні висновки:

- на ринку досконалої та монополістичної конкуренції фрункціонує велика кількість продавців та покупців, для ринку олігополії характерна невелика кількість продавців проте багато покупців, а на монопольному ринку діє один продавець і кількість покупців може бути різною (навіть один покупець);

- на ринку досконалої конкуренції діють переважно малі підприємства, на ринку монополістичної конкуренції фуункціонують малі та середні підприємства, для олігополії та монополії притаманні переважно великі підприємства;

- ринок досконалої конкуренції насичений однотипними товарами, на ринку монополістичної конкуренції та олігополії реалізовуються диференційвані товари, для монополії храктерні унікальні товари та послуги;

- продавці не мають впливу на ринкову ціну за умов досконалої конкуренції, за умов монополістичної конкуренції такий вплив $€$ обмеженим, олігополісти значною мірою

Порівняльний аналіз типів ринкових структур

Таблиця 1

\begin{tabular}{|c|c|c|c|c|}
\hline \multirow{3}{*}{ Характерні ознаки } & \multicolumn{4}{|c|}{ Тип ринкової структури } \\
\hline & \multirow{2}{*}{$\begin{array}{l}\text { Досконала } \\
\text { конкуренція }\end{array}$} & \multicolumn{3}{|c|}{ Недосконала конкуренція } \\
\hline & & $\begin{array}{c}\text { Монополістична } \\
\text { конкуренція }\end{array}$ & Олігополія & $\begin{array}{c}\text { Чиста } \\
\text { монополія }\end{array}$ \\
\hline Кількість продавців & велика & велика & невелика & один продавець \\
\hline Кількість покупців & велика & велика & велика & $\begin{array}{c}\text { різна } \\
\text { (може бути один) }\end{array}$ \\
\hline Розміри підприємств & малі & малі або середні & великі & переважно великі \\
\hline Товари & однотипні & дисреренційовані & $\begin{array}{c}\text { однотипні або } \\
\text { диференційовані }\end{array}$ & унікальні \\
\hline Контроль над цінами & відсутній & обмежений & значний & повний \\
\hline $\begin{array}{c}\text { Бар'єри входу } \\
\text { на ринок }\end{array}$ & відсутні & незначні & значні & $\begin{array}{c}\text { Майже } \\
\text { нездоланні }\end{array}$ \\
\hline $\begin{array}{c}\text { Доступ до інфрормації } \\
\text { на ринку }\end{array}$ & вільний & вільний & обмежений & заблокований \\
\hline Тип конкуренції & нецінова & $\begin{array}{c}\text { нецінова та } \\
\text { обмежена цінова }\end{array}$ & $\begin{array}{c}\text { нецінова та } \\
\text { обмежена цінова }\end{array}$ & $\begin{array}{c}\text { конкуренція } \\
\text { відсутня }\end{array}$ \\
\hline
\end{tabular}


впливають на рівень цін на ринку, монополіст повністю контролює рівень цін на ринку;

- бар'єри входу на монопольний ринок є майже нездоланними, значними в умовах олігополії, незначними за монополістичної конкуренції, відсутні для ринку досконалої конкуренції;

- інформація на ринку досконалої та монополістичної конкуренції $є$ у вільному доступі, для олігополії характерний обмежений доступ до інформації, на монополістичному ринку інфрормація закрита;

- на монопольному ринку конкуренція відсутня, для інших типів характерна переважно нецінова конкуренція, проте олігополія використовує і цінову конкуренцію.

Згалом всі типи ринкових структур умовно можна поділити на реальні та ідельні типи. Більшість рельно діючих ринків можна віднести до олігополії або монополістичної конкуренції. До олігополії можна віднести підприємства по виробництву алюмінію, цигарок, послуги телефронного зв'язку та ін. До монополістичної конкуренції належать переважно підприємства сорери послуг (ресторани, станції технічного обслуговування, банківські установи та ін.), а також можуть бути підприємства з виробництва взуття, одягу. Стосовно досконалої конкуренції та монополії, то вони $€$ більш абстрактними, ідеальними, оскільки існують реальні ринки, які лише наближено відповідають умовам даних ринкових структур. Важко знайти галузь, яку можна однозначно віднести до досконалої конкуренції чи монополії.

Висновки. Високим рівнем економічної ефективності характеризується ринок абсолютної конкуренції, за умови відсутності певних негативних наслідків, до прикладу, екологічних. Стосовно монополістичної конкуренції, то це такий тип ринкової структури, який необхідно регулювати. Значною перевагою даної структури є різноманітність товарів.

Олігополії $\epsilon$ ефективними з точки зору розробки та впровадження певних інновацій, оскільки володіють необхідним рівнем забезпечення. Наявність бар'єрів для входу на ринок надає олігополісту впевненість в тому, що його вкладення в інновації принесуть результат у вигляді прибутку. На основі цього можна спрогнозувати зниження виробничих витрат, рівня цін та збільшен ня обсягів виробництва та рівня зайнятості.

Загалом поширення монополії негативно впливає на рівень економічної ефективності ринку, оскільки монополіст націлений на максимізацію прибутку за мінімальних обсягів виробництва, як наслідок наявні ресурси не використовуються повною мірою та споживачі не отримують необхідну кількість продукції, наявна низька виробнича ефективність.

\section{СПИСОК ВИКОРИСТАНИХ ДЖЕРЕЛ:}

1. Павленко А.В. Монополістичні структури в системі ринкових відносин. Економіка та держава. 2011. № 7. C. 64-66.

2. Стретович О.А. Економічна сутність конкуренції. Економіка та держава. 2010. № 9. С. 17.

3. Фатхутдінов Р.А. Конкурентоспроможність організації в умовах кризи: економіка, маркетинг, менеджмент. Москва : Маркетинг, 2002. С. 316-317.

4. Філіпович В.В. Розвиток теоретичних підходів до класифрікації ринкових структур. Вісник Одеського національного університету. 2010. Т. 15. Вип. 20. С. 227-235.

5. Юданов А.Ю. Конкуренция: теория и практика. Москва : ГНОМ-ПРЕСС, 1998. С. 12.

\section{REFERENCES:}

1. Pavlenko A.V. (2011) Monopolistychni struktury v systemi rynkovykh vidnosyn [Monopolistic structures in the system of market relations]. Economy and state, no. 7, pp. 64-66.

2. Stretovych O.A. (2010) Ekonomichna sutnist konkurentsii [The economic essence of competition]. Economy and state, no. 9, p. 17.

3. Fatkhutdinov R.A. (2002) Konkurentospromozhnist orhanizatsii v umovakh kryzy: ekonomika, marketynh, menedzhment [Competitiveness of the organization in the crisis: economics, marketing, management]. Moscow: Marketing, pp. 316-317.

4. Filipovych V.V. (2010) Rozvytok teoretychnykh pidkhodiv do klasyfikatsii rynkovykh struktur [Development of theoretical approaches to the classification of market structures]. Herald of Odessa National University, vol. 15, no. 20, pp. 227-235.

5. Yudanov A.Yu. (1998) Konkurentsiya: teoriya i praktika [Competition: theory and practice]. Moscow: GNOM-PRESS, p. 12. 